\title{
The Past, Present and Future of Q-Step - A Programme Creating a Step-Change in Quantitative Social Science Skills
}

Steve Grundy

The Nuffield Foundation, sgrundy@nuffieldfoundation.org

Follow this and additional works at: https://digitalcommons.usf.edu/numeracy

Part of the Social and Behavioral Sciences Commons

\section{Recommended Citation}

Grundy, Steve. "The Past, Present and Future of Q-Step - A Programme Creating a Step-Change in Quantitative Social Science Skills." Numeracy 13, Iss. 1 (2020): Article 2. DOI: https://doi.org/10.5038/ 1936-4660.13.1.2 


\title{
The Past, Present and Future of Q-Step - A Programme Creating a Step-Change in Quantitative Social Science Skills
}

\begin{abstract}
This article provides an outline of the conception and implementation to date of Q-Step, a national programme to make high-level quantitative skills an essential element of teaching and learning in social sciences across the UK. Q-Step has supported the development and delivery of specialist undergraduate programmes (including new courses, work placements, and pathways to postgraduate study) in order to increase the number of quantitatively trained social scientists in the UK. There are 17 UK universities currently participating in the programme which has been funded by the Nuffield Foundation, the Economic and Social Research Council (ESRC), and the former Higher Education Funding Council for England (HEFCE). The Nuffield Foundation funds research, analysis, and student programmes that advance educational opportunity and social well-being across the United Kingdom. The Q-Step programme provides opportunities for students to develop skills and confidence in quantitative methods. This is in keeping with the Nuffield Foundation's interest in promoting digital skills and data literacy more generally. The Nuffield Foundation believes that these skills are essential for people to participate fully in a digital knowledge economy.

This article provides the background and rationale leading to Q-Step's inception, some detail on the wider context in which the programme operates, an insight into the progress made by Q-Step so far, and also looks toward the future of the programme and the wider agenda it operates within. This article provides a snapshot of one particular model for building quantitative methods capacity in the UK higher education sector and a useful reference point for understanding the background and context of further studies and articles which might follow from Q-Step universities sharing some of their pedagogical expertise and their experience of teaching social sciences with quantitative methodology.
\end{abstract}

\section{Keywords}

quantitative literacy, social sciences

\section{Creative Commons License}

This work is licensed under a Creative Commons Attribution-Noncommercial 4.0 License

\section{Cover Page Footnote}

Steve Grundy is the Q-Step Programme Manager for the Nuffield Foundation which is based in the UK. Steve is a fully qualified and experienced Careers Adviser with a long-standing interest in supporting skills development for a changing labour market. He has also worked extensively in widening participation/fair access, including leading teams in several universities to develop outreach programmes providing opportunities for disadvantaged students. Steve's other areas of expertise within the higher education sector include managing departments focusing on student support, student experience, teaching \& learning, and academic quality. Steve also has a wide range of experience in the charity sector working mainly on developing partnerships between schools, universities, and industry. 


\section{Introduction to Q-Step}

Since 2012 Q-Step has been at the forefront of a movement to make high-level quantitative skills an essential element of teaching and learning in social sciences across the UK. The initiative intends to create a "big push" in social science education to enhance quantitative skill in these critical fields. Along with the Economic and Social Research Council (ESRC) and Higher Education Funding Council for England (HEFCE), the Nuffield Foundation has co-funded this programme because it relates closely to the organisation's interests, objectives, and remit.

The Nuffield Foundation funds research, analysis, and student programmes that advance educational opportunity and social well-being across the United Kingdom. It aims to improve people's lives and their ability to participate in society by understanding the social and economic factors that affect their chances in life. Research funded by the Nuffield Foundation aims to improve the design and operation of social policy, particularly in relation to education, welfare, and justice.

Alongside funding research, the Nuffield Foundation also funds direct interventions in the form of its flagship student programmes Nuffield Research Placements and Q-Step ${ }^{1}$. These programmes provide opportunities for individual students to develop their skills and confidence in quantitative and scientific methods. The Nuffield Foundation believes that these skills are essential for people to participate fully in a digital knowledge economy.

The Nuffield Foundation is financially and politically independent and, as is the case with Q-Step, will often work with other organisations that share its aims and interests. The following section describes the work that led to the Q-Step programme's design. Subsequent sections describe outputs of the programme and how its centres have developed at various institutions before providing a description of some provisional evaluation findings. The concluding section offers thoughts on how the initiative may evolve moving forward.

\section{Why and How Q-Step Came to Be}

Q-Step was designed to support and build upon previous initiatives from the Nuffield Foundation, Economic and Social Research Council (ESRC), Higher Education Funding Council for England (HEFCE), the British Academy, the Royal Statistical Society (RSS), ${ }^{2}$ and others to improve the UK's longstanding weakness

\footnotetext{
${ }^{1}$ https://www.nuffieldfoundation.org/nuffield-research-placements; https://www.nuffieldfoundation.org/q-step

${ }^{2}$ https://www.nuffieldfoundation.org/; https://esrc.ukri.org/; https://www.gov.uk/government/organisations/higher-education-funding-council-for-england; https://www.thebritishacademy.ac.uk/; https://www.rss.org.uk/
} 
in providing quantitative understanding across all stages of the educational life course, from secondary school to postgraduate level.

These organisations had been concerned for several years about the relative decline in the number of postgraduate students with high-level quantitative skills in subjects other than economics and experimental psychology. It was increasingly apparent that in most UK social science disciplines, only a small and decreasing proportion of the work of new career researchers was in any way quantitative. Yet understanding research design and the role of experiment and structured empirical observation and then critically analysing results are skills in high demand from employers.

In 2005, HEFCE's Strategically Important and Vulnerable Subjects (SIVS) Advisory Group defined quantitative social sciences as strategically important and vulnerable and confirmed that action was essential. Later, Professor MacInnes' 2009 report, Proposals to support and improve the teaching of quantitative research methods at undergraduate level in the $U K$, detailed the extent of the problem (2009). Guided by these and other reports, pilots, and initiatives, the QStep Programme was established in 2012.

Table 1 shows a selection of reports which combined to influence the conception of pilot projects followed by the Q-Step programme.

The plan has been to promote a step-change in quantitative skills training for social science undergraduates and thereby build capacity sustainably over the longer term. The programme has encouraged the development of new and exciting ways of teaching to attract and enthuse students and signal to a wide range of school and university students that quantitative skills can illuminate important research questions and provide a path to interesting careers.

The programme has been co-funded, in a first phase lasting from 2012/13 to 2018/19, by the Nuffield Foundation, ESRC, and the Office for Students (OfS), formerly Higher Education Funding Council for England (HEFCE). Q-Step has:

- $\quad$ promoted institutional change in higher education through increased commitment to the importance of quantitative skills in social science teaching and research;

- $\quad$ produced new undergraduate social science curricula and teaching methodologies that embed quantitative skills in the context of substantive problems and concepts;

- $\quad$ produced a first cohort of quantitatively skilled undergraduates across a range of social science disciplines who have a good understanding of quantitative methods and experience in applying them; and

- developed effective pathways for the application of quantitative skills by creating links between undergraduate and postgraduate training and meeting the needs of academic research and the wider labour market. 
Table 1

A Selection of Reports Preceding and Influencing the Conception of Q-Step.

\begin{tabular}{|c|c|c|c|}
\hline Title & Author & Publisher & Year \\
\hline $\begin{array}{l}\text { Horizons and Opportunities in the Social } \\
\text { Sciences }\end{array}$ & id. & ESRC & 1987 \\
\hline $\begin{array}{l}\text { Signs of Disintegration: A Report on UK } \\
\text { Economics PhDs }\end{array}$ & Oswald, A. and S. Machin & ESRC & 1999 \\
\hline $\begin{array}{l}\text { An Enquiry into the Use of Numeric Data in } \\
\text { Learning \& Teaching: Report and } \\
\text { Recommendations for UK Higher } \\
\text { Education }\end{array}$ & Rice, R. et al. & University of Edinburgh & 2001 \\
\hline $\begin{array}{l}\text { SET for Success: The Supply of People with } \\
\text { Science, Technology, Engineering and } \\
\text { Mathematics Skills: The Report of Sir } \\
\text { Gareth Roberts Review }\end{array}$ & id. & HM Treasury & 2002 \\
\hline $\begin{array}{l}\text { Great Expectations: A Review of the UK Social } \\
\text { Sciences }\end{array}$ & Rhind, D. & ALSISS & 2003 \\
\hline $\begin{array}{l}\text { Making Mathematics Count: The Report of } \\
\text { Professor Adrian Smith's Inquiry into } \\
\text { Post-14 Mathematics Education }\end{array}$ & Smith, A. & DFES & 2004 \\
\hline $\begin{array}{l}\text { Baseline Study of Quantitative Methods in } \\
\text { British Sociology }\end{array}$ & Williams, M. et al. & C-SAP/ BSA & 2004 \\
\hline $\begin{array}{l}\text { 14-19 Education and Skills, Government White } \\
\text { Paper }\end{array}$ & id. & DFES & 2005 \\
\hline $\begin{array}{l}\text { The Employment of Social Science PhDs in } \\
\text { Academic and Non-academic Jobs: } \\
\text { Research Skills and Postgraduate } \\
\text { Training, A Report Prepared for the } \\
\text { ESRC Training and Development Board }\end{array}$ & Purcell, K. et al. & ESRC & 2005 \\
\hline $\begin{array}{l}\text { Teaching and Learning Research Capability } \\
\text { Building Network. Final Report to the } \\
\text { ESRC }\end{array}$ & Rees, G. and S. Gorard & ESRC & 2005 \\
\hline $\begin{array}{l}\text { A Review of Strategically Important and } \\
\text { Vulnerable Subjects. }\end{array}$ & Roberts, G. & HEFCE & 2005 \\
\hline $\begin{array}{l}\text { Assessment of Needs for Training in Research } \\
\text { Methods in the UK Social Science } \\
\text { Community }\end{array}$ & Wiles, R. & ESRC & 2005 \\
\hline $\begin{array}{l}\text { Demographic Review of the UK Social } \\
\text { Sciences }\end{array}$ & Mills, D. et al. & ESRC & 2006 \\
\hline $\begin{array}{l}\text { Report of the Workshop on Enhancing the UK } \\
\text { Social Science Skills Base in } \\
\text { Quantitative Methods: Developing } \\
\text { Undergraduate Learning }\end{array}$ & id. & ESRC & 2007 \\
\hline $\begin{array}{l}\text { Scoping Study into Quantitative Methods } \\
\text { Capacity Building in Wales, Final report } \\
\text { to the ESRC and HEFCW }\end{array}$ & Lynch, R. et al. & ESRC & 2007 \\
\hline $\begin{array}{l}\text { Scoping Study into Quantitative Methods } \\
\text { Capacity Building in Scotland, Final } \\
\text { Report }\end{array}$ & McVie, S. et al. & ESRC & 2008 \\
\hline $\begin{array}{l}\text { International Benchmarking Review of Best } \\
\text { Practice in the Provision of } \\
\text { Undergraduate Teaching in Quantitative } \\
\text { Methods in the Social Sciences }\end{array}$ & Parker, J. et al. & ESRC & 2008 \\
\hline $\begin{array}{l}\text { Enhancing the Integration of Quantitative } \\
\text { Methods Skills in Undergraduate Social } \\
\text { Sciences Curricula }\end{array}$ & Falkingham, Jane et al. & ESRC & 2009 \\
\hline
\end{tabular}


Following an open competitive process, the co-funding partners awarded grants to social science departments in fifteen universities to establish Q-Step Centres to work toward these objectives.

In addition to the 15 Q-Step Centres, a Q-Step Affiliate status was developed to recognise and support other universities planning to develop and increase their existing quantitative skills training in their own social science undergraduate programmes. The addition of Affiliates extended the network of participating institutions to 18 (see Fig. 1 for a map of the original Q-Step Centres):

The Centres: University of Bristol: University of Cardiff; City University, University of Edinburgh; University of Exeter; University of Glasgow; University of Kent; University of Leeds; University of Manchester; Manchester Metropolitan University; University of Oxford; Queen's University Belfast; University of Sheffield; University College London; University of Warwick.

The Affiliates: University of Essex; University of Nottingham; University of Southampton.

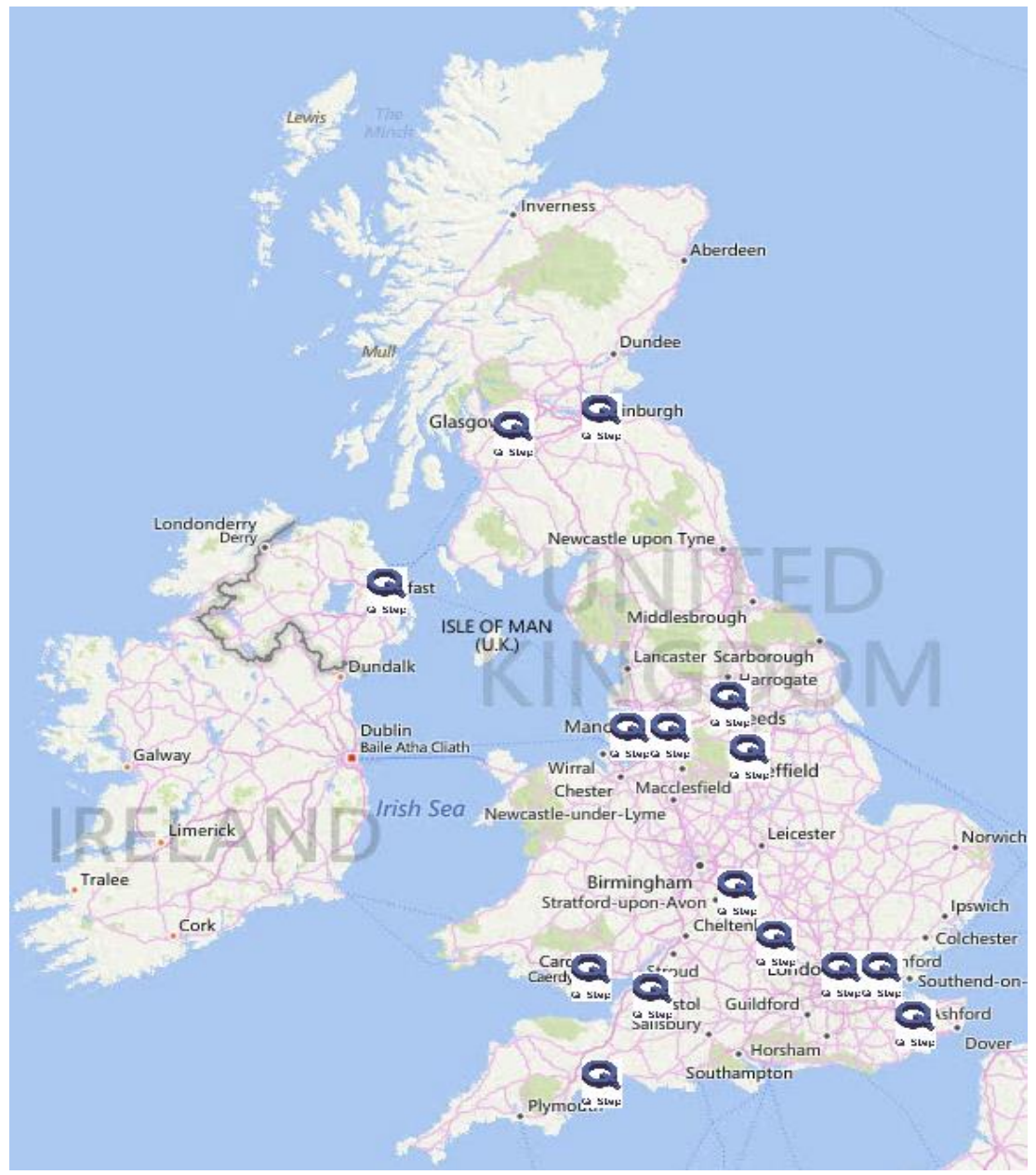

Figure 1. Map showing the spread of the 15 original Q-Step Centres. Universities of Essex and Nottingham have since also become Centres having previously been Affiliates 
An additional two-year transitional period will occur from 2019/20 to 2020/2021 funded by the Nuffield Foundation and the ESRC. During this transitional phase, strategic decisions will be made about the programme's future and possible directions of travel. These decisions will be informed largely by independent evaluation of the programme, due to be reported in 2020. It is a critical time for the Q-Step Programme with plenty of exciting possibilities. During the transition period there will no longer be a distinction between Centres and Affiliates. Each participating institution will be funded at a similar level and they will all become Q-Step Centres. Collaboration and networking between the Centres will be an essential element of the transitional phase.

\section{Defining 'Quant Skills'}

We've mentioned quantitative skills a lot. How do we define this term? What sort of skills are we really talking about? The focus of Q-Step is on developing skills defined along these lines "The ability to reason using numbers ... confidence in the manipulation of numbers; an understanding of the possibilities and limits of measurement; and understanding the role of evidence in testing and modifying our understanding of social processes" (Mansell 2015). More specifically, we define quantitative skills as including the ability to:

- design surveys and experiments, and how to analyse and interpret the data they generateessentially how to design and undertake your own research.

- analyse and interpret data from other sources, such as social media data, data collected by government departments and agencies, and data from longitudinal cohort studies.

- evaluate the quality of data collection and analysis as well as develop an understanding of what constitutes good - and bad! - evidence and how you can use it to make decisions (Nuffield Foundation 2016).

An even more detailed understanding of what we mean by 'quant skills' and 'good, comprehensive quant methods training' can be acquired via perusal of the 35 benchmarks (Krčál and Bryan 2018) which provide a good outline of much of the teaching and learning on Q-Step Programmes.

\section{Outputs}

So what has the Q-Step Programme done and what has it produced? Table 2 provides a snapshot of some of the outputs. The numbers in the table are accurate at the time of writing but will change as the programme continues to progress and expand. The evaluators estimate that the number of Q-Step students represents circa 40 per cent of the total number of students that enrol in (comparable) social sciences courses across the 18 Q-Step Centres and Affiliates. Put in the wider context of the sector as a whole, the number of students with high exposure to Q-Step is relatively 
low in comparison with the total number of undergraduate students in social sciences. This finding is not surprising since the programme only covers $18 \mathrm{HE}$ providers, but it provides a sense of scale and a raises a question over the programme's ability to single-handedly diminish the shortage of quantitativelyskilled social science graduates in the UK.

Table 2

Q-Step Programme Outputs

\begin{tabular}{|c|c|}
\hline Number of degree programmes & 68 new or modified \\
\hline Number of modules & 185 new or modified \\
\hline Number of students starting quantitative degree programmes & 1940 \\
\hline Number of students taking quantitative modules & 9564 \\
\hline Number of students on placements/internships & 864 since Programme began \\
\hline Number of employers involved & 424 \\
\hline Subjects covered & $\begin{array}{l}\text { Education, geography, international relations, law, } \\
\text { linguistics, political science, population health, PPE, and } \\
\text { sociology (see note) }\end{array}$ \\
\hline Number of staff involved (including coordinators) & $\begin{array}{l}52 \text { new hires ( } 28 \text { non-UK), } 18 \text { Coordinators and } 7 \\
\text { Deputy/Co-Coordinators }\end{array}$ \\
\hline
\end{tabular}

In addition to the numerical outputs in Table 2, which relate to the core programme of quantitative teaching and learning that Q-Step has established across the 18 institutions, there are many other associated outputs which contribute to the impact of Q-Step. For example, Q-Step institutions have produced a vast array of teaching and learning materials which we are currently collecting with the intention of curating and sharing openly. Q-Step staff and students have also produced numerous and incredibly varied academic research papers and reports for the public and private sectors, for industry as well as government departments. The Q-Step Programme has also provided events and activities that teach key data skills, for example via summer schools, bootcamps, Continued Professional Development training sessions, and latterly, bespoke consultancy.

\section{Q-Step in Context}

For Q-Step to fully meet its objectives, it needs to find its place within a wider context. It needs to reach other universities (where quant skills are not welldeveloped in the social sciences), secondary schools (to excite students about quantitative social sciences as a choice for study), employers (to help them utilise 
the STEM skills developed by Q-Step graduates and to help shape the way in which these are developed), learned societies, subject and professional associations (to provide additional professional leadership for quantitative skills), and the examination awarding bodies (to ensure that these skills are seen as pivotal to successful social science study) to form a groundswell of support.

Through events such as the 2018 symposium, social media, publications, and outreach work, Q-Step has begun to influence other social science providers beyond the immediate set of recognised universities. ${ }^{3}$ The Q-Step programme is working in collaboration with other bodies that share an interest in developing quantitative skills generally and specifically within the social sciences. Some of these partners and collaborators are included in Table 3 . These projects and organisations share a common vision, one encouraged by the Nuffield Foundation, of the need for students/academics/citizens to be able to utilise, manage, interpret, and explain data to better understand the subject they are embedded within.

\section{Evaluation}

The Q-Step Programme has already benefitted from a midterm review during academic year 2015/16 which identified specific challenges in areas including marketing and student recruitment; student tracking and student data; understanding benchmarks and pedagogy; and sharing experience, expertise, and materials.

An independent evaluation of the programme is due to report fully and publicly in 2020. Meanwhile, the evaluators have produced an interim report. The interim report provides an analysis of the programme data, the results from qualitative analysis based on interviews and focus groups which took place at all 18 Q-Step Centres and Affiliates, and quantitative analysis (econometric analysis) using Higher Education Statistics Agency (HESA) data. Although the interim report is not for publication, some of its headlines are shared in broad terms below.

\section{The Set-up of Q-Step}

The interim report encourages us to think that Q-Step is successfully building on previously funded initiatives which suggests it has effectively utilised what has gone before in order to secure the progress it has made. The evaluation also shows that, through widespread implementation of internal advisory boards comprising senior leaders in each respective institution, in almost all Q-Step Centres there is a level of strategic support from the institution to embed more quantitative skills in undergraduates and recognise the importance of these skills to social science

${ }^{3}$ https://www.nuffieldfoundation.org/quantitative-skills-teaching-and-learning-symposiumbeyond-\%E2\%80\%98don\%E2\%80\%99t-want-teach-don\%E2\%80\%99t-want-learn\%E2\%80\%99 
graduates. We believe that this internal support is crucial to the success of the programme.

Table 3

A Selection of Organisations and Bodies that Share Similar Interests to Q-Step

\begin{tabular}{|c|c|}
\hline$\overline{\text { Organisation }}$ & Description \\
\hline The British Academy ${ }^{4}$ & $\begin{array}{l}\text { The UK's national body for the humanities and social sciences-the } \\
\text { study of peoples, cultures and societies, past, present and future }\end{array}$ \\
\hline The Alan Turing Institute ${ }^{5}$ & $\begin{array}{l}\text { The national institute for data science and artificial intelligence, } \\
\text { headquartered at the British Library }\end{array}$ \\
\hline The National Centre for Research Methods ${ }^{6}$ & $\begin{array}{l}\text { A partnership between the Universities of Southampton, Edinburgh and } \\
\text { Manchester, supported by ESRC, and interested in methodological } \\
\text { research and training in the social sciences }\end{array}$ \\
\hline UK Data Service $^{7}$ & $\begin{array}{l}\text { A partnership between the Universities of Essex and Manchester, } \\
\text { supported by ESRC, and tasked with providing researchers with training } \\
\text { and access to the UK's largest collection of social, economic and } \\
\text { population data. }\end{array}$ \\
\hline $\mathrm{AQMeN}^{8}$ & $\begin{array}{l}\text { A provider of training, capacity building and knowledge exchange } \\
\text { activities in the area of statistical methods and data analysis. }\end{array}$ \\
\hline National Numeracy ${ }^{9}$ & $\begin{array}{l}\text { An independent charity aiming to raise levels of numeracy among both } \\
\text { adults and children and to promote the importance of everyday } \\
\text { mathematics skills. }\end{array}$ \\
\hline The Royal Economic Society ${ }^{10}$ & $\begin{array}{l}\text { A national body whose purpose is to promote the study of economic } \\
\text { science. }\end{array}$ \\
\hline Royal Geographical Society ${ }^{11}$ & The UK's learned society and professional body for geography. \\
\hline CORE Economics ${ }^{12}$ & $\begin{array}{l}\text { An organisation that creates and distributes open-access teaching } \\
\text { material for economics curriculum form. }\end{array}$ \\
\hline
\end{tabular}

Interestingly the report suggests that most Q-Step institutions have experienced challenges in recruiting students directly to their quantitative methods degree pathways. Often it has been less challenging to recruit students onto one or two modules with a quantitative focus rather than a full degree with quantitative methods pathway. Many students have relied on referrals through transfers into the course or through 'clearing,' i.e., those students who do not attain the required grades for their desired course and are offered alternative courses. The difficulty in

\footnotetext{
${ }^{4}$ https://www.thebritishacademy.ac.uk/ and https://www.thebritishacademy.ac.uk/policy/highlevel-strategy-group-quantitative-skills

${ }^{5}$ https://www.turing.ac.uk/ and https://www.accenture.com/gb-en/data-skills-taskforce

${ }^{6}$ https://www.ncrm.ac.uk/

7 https://ukdataservice.ac.uk/

8 http://www.aqmen.ac.uk/

${ }^{9}$ https://www.nationalnumeracy.org.uk/

${ }^{10}$ https://www.res.org.uk/

${ }^{11}$ https://www.rgs.org/

12 https://www.core-econ.org/
} 
recruiting has been attributed by coordinators and academics to a perception among prospective students that Q-Step degree pathways are all about mathematics.

\section{The Implementation of Q-Step}

It is very clear from the evaluators' profile of each institution that different approaches have been taken to coordination and internal management of the Q-Step programme within each institution. This variation of approaches is not unexpected given that the programme has been deliberately experimental to a large degree. Factors that affect the approach taken include current institutional practices as well as the number of departments involved (and therefore whether one department or several departments lead the management). Not enough evidence exists at this point in the evaluation to distinguish between the effectiveness of approaches to management and coordination. The institutional profiles present clear reasons as to why each centre has chosen its own approach. We expect to be able to share more on the profiling exercise when we publish the full evaluation report in 2020.

The evaluation is already providing an insight into the levels of employer involvement in Q-Step institutions. This employer engagement varies, with deeper engagement beyond placements happening in half of the institutions. Employer engagement takes different forms such as guest lectures, course feedback, and in a few cases formal involvement in steering groups. Interviews with academic staff also suggest a growing appetite from employers to engage in the design of degrees and modules.

Student satisfaction with Q-Step implementation is also being analysed as part of the evaluation. Data from student surveys provide some encouraging indications that satisfaction levels are high, particularly in relation to the teaching approaches, quality of learning support (and additional support services), and placements. Rather usefully though, the interim evaluation report also highlights areas where students feel improvements could be made. For example, effectively balancing theory and practice and increasing the use of mixed methods teaching (e.g., the combination of quantitative and qualitative approaches) are potential areas for improvement, according to students.

\section{The Outcomes of Q-Step}

Interim findings based on student attainment in assessments give us some encouraging signs of an uplift in students' quantitative skills and their potential to further their academic careers. For example, increasing numbers of students are progressing onto master's degrees with quantitative methods and/or a $\mathrm{PhD}$ programme with quantitative pathways.

An increase in the number of placements offered by employers, including many who offer placements year after year, seems to suggest that the skills Q-Step students learn are relevant and possibly even in high demand in the labour market. 
Feedback that we have collected from placement hosts confirms this finding. The evaluators will continue to investigate Q-Step's relevance to the needs of the labour market before reporting fully in 2020. In the meantime we suspect that Q-Step students are proving popular with employers because their programmes of study include relevant content taught through delivery modes that provide valuable experience (for example work placements, exposure to real world problems, the use of common statistical packages, and applying knowledge and skills appropriately).

The evaluation also indicates that at the institutional level Q-Step has catalysed discourse about the importance of teaching and research and the balance between the two. This indication comes partly as a reflection on the introduction of the Teaching Excellence Framework (TEF) ${ }^{13}$. Q-Step, as a teaching initiative, is considered by several of the participating institutions as an example of their gradual re-orientation toward high quality teaching, and the programme was mentioned in multiple TEF submissions. Meanwhile, our annual monitoring reports from each Q-Step Centre provide us with details of the strong contribution that Q-Step Centres are making to their respective institutions' research profiles. A handful of Q-Step Centres also report, via their respective advisory boards, that the implementation of Q-Step provides a platform for academics and institutional leadership to discuss the balance between quantitative and qualitative approaches in a more systematic way.

\section{The Sustainability of Q-Step}

The evaluation's interim findings lead us to think that institutions tend to have a common perception of what the critical factors are in relation to the sustainability of Q-Step. These factors include securing a critical mass in Q-Step staffing and ensuring the training of new staff through $\mathrm{PhDs}$ and post-docs; obtaining institutional support and leadership endorsement; ensuring enough resource is given to the administration of the Q-Step programme; and some degree of facilitation at a national level of programme promotion, stakeholder engagement, and sharing materials and good practice.

\section{What's Next for Q-Step?}

Whilst we believe that Q-Step has already made a notable and, we hope, lasting contribution to quantitative teaching and learning in UK undergraduate social sciences, its influence is by no means comprehensive. The programme's next challenges include:

- expanding and developing the skills base in the participating universities.

- taking lessons learned to other providers of social science undergraduate teaching and learning.

${ }^{13}$ https://www.officeforstudents.org.uk/advice-and-guidance/teaching/what-is-the-tef/ 
- helping young people at school understand what quantitative social science entails, the careers that can be accessed by such qualifications, and encouraging the continued use of data/numeracy skills beyond age 16 .

- ensuring that postgraduate provision builds on the quantitative skills acquired at undergraduate level.

- working with employers to develop their understanding of the skills fostered by QStep undergraduate teaching and learning.

- potentially experimenting with embedding quantitative skills in the humanities and other subject domains.

- using 'lessons learned' to work with colleagues establishing digital skills development at undergraduate level.

As mentioned earlier in this article, from 2019/20 to 2020/21, there will be a two-year transitional period for the Q-Step Programme. The transitional period is intended to provide a degree of continuity as institutions prepare their strategies for ensuring the longer-term sustainability of the programme. We believe that Q-Step has come a long way since its inception. More importantly, the agenda to promote quantitative methods in the social sciences in the UK has progressed significantly with the support of the initiative and the proactive implementation of the Q-Step Programme. Having provided this summary of the past, present, and future of the programme, we look forward to sharing further articles from across the network of Q-Step Centres. We particularly hope to share more insight into the pedagogies and methodologies used by the Centres, more about their experiences of embedding quantitative approaches in social science courses, and of course more from the independent evaluation of the programme.

\section{References}

Department for Education and Skills. 2005. "14-19 Education and Skills, Government White Paper.” DfES.

Economic and Social Research Council. 1987. "Horizons and Opportunities in the Social Sciences." ESRC

Economic and Social Research Council. 2007. "Report of the Workshop on

Enhancing the UK Social Science Skills Base in Quantitative Methods:

Developing Undergraduate Learning." ESRC.

Falkingham, Jane et al. 2009. "Enhancing the Integration of Quantitative Methods Skills in Undergraduate Social Sciences Curricula." ESRC.

HM Treasury. 2002. "SET for Success: The Supply of People with Science, Technology, Engineering and Mathematics Skills: The Report of Sir Gareth Roberts Review.” HM Treasury.

Krčál, Adam and Billy Bryan. 2018. "Q-Step Benchmarking, a report by

Technopolis Group" 
https://www.nuffieldfoundation.org/sites/default/files/files/Q-

Step\%20Benchmarking\%20report_v_2FINAL.pdf

Lynch, R., G. Maio, G. Moore, L. Moore, S. Orford, A. Robinson, C. Taylor, and

K. Whitfield. 2007. "Scoping Study into Quantitative Methods Capacity

Building in Wales. Final report to the ESRC and HEFCW." ESRC.

MacInnes, John. 2009. "Proposals to Support and Improve the Teaching of

Quantitative Research Methods at Undergraduate Level in the UK."

Economic Social and Research Council.

https://esrc.ukri.org/files/research/qmi/final-report-strategic-advisor-for-

quantitative-methods-proposals-to-support-and-improve-the-teaching-of-

quantitative-research-methods-at-undergraduate-level-in-the-uk/

Mansell, Warwick. 2015. "Count Us In-Quantitative Skills for a New

Generation." The British Academy.

https://www.thebritishacademy.ac.uk/sites/default/files/Count-Us-In-Full-

Report.pdf

McVie, S., A. Coxon, P. Hawkins, J. Palmer, and R. Rice. 2008. "Scoping Study into Quantitative Methods Capacity Building in Scotland. Final Report." ESRC.

Mills, D. et al. 2006. "Demographic Review of the UK Social Sciences." ESRC.

Nuffield Foundation. 2016. "Shaping Society-Quantitative Social Science for the 21st Century."

Oswald, A. and S. Machin. 1999. "Signs of Disintegration: A Report on UK Economics PhDs." ESRC.

Parker, J. et al. 2008. "International Benchmarking Review of Best Practice in the Provision of Undergraduate Teaching in Quantitative Methods in the Social Sciences." ESRC.

Purcell, K., S. Durbin, S. Warren, P. Elias, H. Behle, and R. Davies. 2005. "The Employment of Social Science PhDs in Academic and Non-academic Jobs: Research Skills and Postgraduate Training. A report prepared for the ESRC Training and Development Board." ESRC.

Rees, G. and S. Gorard. 2005. "Teaching and Learning Research Capability Building Network. Final Report to the ESRC." ESRC.

Rhind, D. 2003. "Great Expectations: A Review of the UK Social Sciences." ALSISS.

Rice, R., P. Burnhill, M. Wright, and S. Townsend. 2001. "An Enquiry into the Use of Numeric Data in Learning \& Teaching: Report and Recommendations for UK Higher Education." University of Edinburgh. https://doi.org/10.29173/iq581

Roberts, G. 2005. "A Review of Strategically Important and Vulnerable Subjects." HEFCE. 
Smith, A. 2004. "Making Mathematics Count: The Report of Professor Adrian Smith's Inquiry into Post-14 Mathematics Education.” DFES.

Wiles, R. 2005. "Assessment of Needs for Training in Research Methods in the UK Social Science Community." ESRC.

Williams, M., C. Collett, and R. Rice. 2004. "Baseline Study of Quantitative Methods in British Sociology." C-SAP/ BSA. 